\title{
Three-year experience of using venovenous extracorporeal membrane oxygenation for patients with severe respiratory failure
}

\author{
George WY Ng *, Anne KH Leung, KC Sin, SY Au, Stanley CH Chan, Osburga PK Chan, Helen HL Wu
}

\section{A B S T R A C T}

Objective: To present the 3-year experience of using venovenous extracorporeal membrane oxygenation for patients with severe respiratory failure in a single centre in Hong Kong.

Design: Case series.

Setting: A 19-bed Intensive Care Unit of a tertiary hospital in Hong Kong.

Patients: All patients who were managed with venovenous extracorporeal membrane oxygenation from 1 July 2010 to 30 June 2013 in the Intensive Care Unit.

Results: Overall, 31 patients (mean age, 42.2 years, standard deviation, 14.1 years; 21 males) received venovenous extracorporeal membrane oxygenation for the treatment of severe respiratory failure. Of these, $90.3 \%$ ( 28 patients) presented with pneumonia as the cause of the respiratory failure, and 22 of them had identifiable causes. A total of nine (29.0\%) patients were diagnosed to have H1N1 infection. The median Murray score was 3.5 (interquartile range, 3.0-3.5); the median duration of venovenous extracorporeal membrane oxygenation support was 5.0 (2.8-8.6) days; and the median duration of mechanical ventilator support was 18.2 (7.8-27.9) days. The overall intensive care unit mortality was

This article was published on 20 Jun 2014 at www.hkmj.org.
$19.4 \%(n=6)$. The overall in-hospital mortality and the 28 -day mortality were both $22.6 \%(n=7)$. Among the 22 patients who had identifiable infective causes, those suffering from viral infection had lower intensive care unit and hospital mortality than those who had bacterial infection (8.3\% vs $20.0 \%)$. All the H1N1 patients survived. Complications related to extracorporeal membrane oxygenation included severe bleeding $(n=2 ; 6.5 \%)$ and mechanical complications of the circuits $(n=3 ; 9.7 \%)$.

Conclusions: Venovenous extracorporeal membrane oxygenation is an effective adjunctive therapy and can be used as a life-saving procedure for carefully selected patients with severe acute respiratory distress syndrome when the limits of standard therapy have been reached.

\section{Hong Kong Med J 2014;20:407-12 \\ DOI: $10.12809 / \mathrm{hkmj} 144211$ \\ GWY Ng *, FHKAM (Medicine), MPH (HKU) \\ AKH Leung, MB, ChB, FHKAM (Anaesthesiology) \\ KC Sin, MB, ChB, FHKAM (Medicine) \\ SY Au, MB, BS, FHKCP \\ SCH Chan, MB, BS, FHKCA \\ OPK Chan, MB, BS, FHKAM (Medicine) \\ HHL Wu, MB, BS, FHKAM (Medicine)}

Department of Intensive Care, Queen Elizabeth Hospital, 30 Gascoigne Road, Kowloon, Hong Kong

* Corresponding author: georgeng@ha.org.hk

New knowledge added by this stud

- Venovenous extracorporeal membrane oxygenation (ECMO) has become a reliable respiratory support for patients with severe respiratory failure due to acute respiratory distress syndrome and severe hypoxaemia despite the use of conventional therapy.

- Use of venovenous ECMO allows protective ventilation and reduces ventilator-induced lung injury.

- H1N1 patients had a very good survival outcome when they received ECMO therapy.

Implications for clinical practice or policy

- ECMO is available in specialised centres in Hong Kong. Patients with severe acute respiratory distress syndrome, particularly after H1N1 pneumonia, will be good candidates for receiving ECMO treatment.

- ECMO therapy is safe but associated with complications.

\section{Introduction}

Acute respiratory distress syndrome (ARDS), after severe viral or bacterial infection, is a common cause of severe respiratory failure in the Intensive Care Unit (ICU). The syndrome is defined as acute onset of hypoxaemic respiratory failure, which is accompanied by bilateral infiltrates of chest, and occurs due to non-cardiogenic cause. ${ }^{1,2}$ Despite vigorous researches on pharmacological treatment and ventilator strategy in recent decades, ARDS with 


\section{為嚴重呼吸衰竭患者提供 靜脈一靜脈體外膜氧合：三年經驗分享}

吳榮耀、梁結雄、洗佳卓、區碩賢、陳才雄、陳碧姬、胡曉琳

目的：報告香港一個深切治療病房在過去三年為嚴重呼吸衰竭患者提 供靜脈一靜脈體外膜氧合 ( v-v ECMO ) 的經驗。

設計：病例系列。

安排：香港一所提供第三層醫療服務的醫院內的深切治療病房 ( ICU )

患者：2010年 7 月 1 日至2013年6月30日期間所有在 ICU接受 $v-v$ ECMO治療的患者。

結果：因嚴重呼吸衰竭而須接受 $v-v$ ECMO治療的 31 名患者, 他們的 平均年齡為42.2歲（標準差, 14.1歲）；其中21名為男性。患者中 有 $90.3 \%$ （28名）被診斷因肺炎引致呼吸衰竭, 其中 22 人有可識別的 感染原因。9名患者 $(29.0 \%)$ 被確診為H1N1 甲型流感感染。患者的 Murray評分中位數為3.5（介乎3.0至3.5）；使用 $v-v$ ECMO的中位 數時間為5.0（2.8至8.6）天；須機械通氣的中位數時間為 18.2（7.8 至27.9 ) 天。在這 31 名患者中, ICU死亡率為 $19.4 \%(n=6)$ 。住院 死亡率和 28 天死亡率均為 $22.6 \%(n=7)$ 。在 22 名可識別肺部感染原 因的患者中, 因受病毒感染而要接受 $v-v$ ECMO的患者, 比受細菌感 染的患者有較低的ICU死亡率和住院死亡率（8.3\%比20.0\%）。所有 H1N1流感患者成功存活。在接受體外膜氧合期間, $6.5 \%(n=2)$ 出 現嚴重出血, $9.7 \%(n=3)$ 出現因體外膜氧合機件引起的併發症。

結論：v-v ECMO是一種有效挽救生命的輔助治療。有嚴重呼吸衰竭 之患者, 若接受常規治療後沒有好轉, 可選擇接受 $v-v$ ECMO

profound hypoxaemia continues to be associated with high mortality rate. In 2009, the conventional ventilatory support versus extracorporeal membrane oxygenation (ECMO) for severe adult respiratory failure (CESAR) trial, conducted by Peek et $\mathrm{al}^{3}$ in the UK, showed a significant survival advantage with the use of ECMO for patients with severe ARDS. Extracorporeal membrane oxygenation is a life-support technology with a history of more than 40 years. ${ }^{4}$ With the evolution of technology, the procedure has become simpler, safer, and more reliable. Since 2010, the Queen Elizabeth Hospital (QEH) in Hong Kong has started providing venovenous (v-v) ECMO to selected patients with severe respiratory failure due to severe ARDS and profound hypoxaemia.

\section{Methods}

This was a retrospective observational study performed in a 19-bed ICU of a tertiary hospital in Hong Kong. Eligible patients needed to have potentially reversible causes for respiratory failure, refractory respiratory failure despite maximum conventional ventilator support, and Murray score of 3.0 or higher (Murray score ${ }^{4}$ is calculated by: $\mathrm{PaO}_{2} /$ $\mathrm{FiO}_{2}$ ratio, positive end-expiratory pressure [PEEP], lung compliance, chest radiographic appearance). Patients with acute-status asthmaticus and refractory respiratory failure were also selected as candidates for ECMO despite having Murray score of lower than 3.0. Patients were excluded for ECMO therapy if they had intracranial bleeding; severe, irreversible brain damage; or were older than 70 years.

\section{Extracorporeal membrane oxygenation retrieval}

The QEH ECMO team supports eligible patients from other ICUs that do not have ECMO service. The QEH ECMO retrieval team puts eligible patients in the referring hospitals on ECMO circuit, and then escorts them to QEH. The team consists of two intensivists and two intensive care nurses.

\section{Technique of extracorporeal membrane oxygenation setup}

Access catheters (Maquet HLS, Germany; BIOLINE coating) were inserted in either the right or left femoral vein, and return catheters were inserted in the right internal jugular vein. All cannulation procedures were performed at the bedside, by ICU specialists, with Seldinger technique and ultrasound guidance. The size of the cannulas was chosen according to the body weight of patients. The default size was $19 \mathrm{Fr}$ for return catheter and $23 \mathrm{Fr}$ for access catheter. The jugular-femoral approach for return $(19 \mathrm{Fr})$ and access $(23 \mathrm{Fr})$ catheter cannulation was adopted for all patients. The catheters were connected to the ECMO machine (either Rotaflow: BE-PLS 12050-Quadrox PLS [Jostra], or Cardiohelp: HLS module advanced 7.0).

\section{Extracorporeal membrane oxygenation care}

As per our ICU ECMO protocol, ECMO nurses and ECMO specialists have to provide special regular monitoring of coagulation status, circuit conditions, perfusion status, and neurological status. Accordingly, unfractionated heparin infusion is the default and only anticoagulant used. Anticoagulation is monitored at the bedside with a target-activated clotting time of 180-220 seconds. Activated clotting time is measured every 4 hours. We maintain a platelet count of $100 \mathrm{x}$ $10^{9} / \mathrm{L}$, international normalised ratio of $<1.5$, and haemoglobin level of $>120 \mathrm{~g} / \mathrm{L}$. The ECMO nurses need to check the following every 4 hours: presence of clot in the oxygenator membrane, any colour difference between the access and return catheters, and oxygenator membrane pressure gradient. The post-oxygenator partial pressure of oxygen and freehaemoglobin level are checked daily.

\section{Other routine care}

We use benzodiazepine and narcotics for sedation. 
Pupil size, sedation score, and conscious status are assessed every 4 hours. Propofol is not recommended due to the potential interaction with oxygenator membrane. Enteral nutrition is used when possible, and as early as possible, according to our ICU feeding protocol. Fluid balance is maintained with diuretics and continuous $\mathrm{v}-\mathrm{v}$ haemofiltration, as clinically indicated.

\section{Ventilation strategy}

Once the ECMO support is started, we change the ventilator setting so as to allow 'lung rest' (ie $\mathrm{FiO}_{2}$ 0.4 , PEEP $10 \mathrm{~cm} \mathrm{H}_{2} \mathrm{O}$, tidal volume $4 \mathrm{~mL} / \mathrm{kg}$, rate 10 cycles/min) with an inspiratory/expiratory ratio of $1: 1.3$.

\section{Renal replacement therapy}

Continuous v-v haemofiltration is used for patients with acute kidney injury, excessive fluid gain, and metabolic acidosis. The venous and arterial lines are connected at post-pump to minimise the risk of air embolism.

\section{Decannulation}

Heparin infusion is stopped 30 minutes before decannulation. Decannulation is performed at the bedside with two-team approach. Both jugular and femoral catheters are removed simultaneously. Direct pressure is then applied to the sites for at least 15 minutes.

\section{Statistical analysis}

Normally distributed data were expressed as mean \pm standard deviation (SD). Independent $t$ test was used for comparison of means. Data, if not normally distributed, were expressed as median and interquartile range (IQR). Mann-Whitney $U$ test was used for comparison of medians. Categorical data were analysed using Fisher's exact test. Statistical analysis was performed using the Statistical Package for the Social Sciences (Windows version 17; SPSS Inc, Chicago [IL], US). $P$ values of $<0.05$ were considered statistically significant.

\section{Ethics review}

This proposal was reviewed and approved by the Research Ethics Committee of the Kowloon Central Cluster/Kowloon East Cluster (Kowloon Central/ Kowloon East; REC [KC/KE]).

\section{Results}

Between 1 July 2010 and 30 June 2013, 31 patients

TABLE I. Baseline characteristics of the patients treated with extracorporeal membrane oxygenation

\begin{tabular}{|c|c|c|c|c|}
\hline \multirow[t]{2}{*}{ Characteristic } & \multicolumn{3}{|c|}{ Data* } & \multirow[t]{2}{*}{$P$ valuell } \\
\hline & Overall $(n=31)$ & ICU survivors $(n=25)$ & $\begin{array}{c}\text { ICU non-survivors } \\
(n=6)\end{array}$ & \\
\hline Age (years) & $42.2 \pm 14.1$ & $41.6 \pm 12.8$ & $44.8 \pm 19.8$ & $0.62^{A}$ \\
\hline Sex & & & & $0.07^{\mathrm{B}}$ \\
\hline Female & $10(32.3)$ & $6(24.0)$ & $4(66.7)$ & \\
\hline Male & $21(67.7)$ & $19(76.0)$ & $2(33.3)$ & \\
\hline BMI $\left(\mathrm{kg} / \mathrm{m}^{2}\right)$ & $22.6(21.5-24.8)$ & $22.5(21.6-24.6)$ & $24.4(19.6-25.7)$ & $0.73^{c}$ \\
\hline Pre-ECMO $\mathrm{PaO}_{2} / \mathrm{FiO}_{2}$ ratio & $78.0(56.3-99.0)$ & 78.9 (58.9-101.3) & $58.1(50.4-100.3)$ & $0.41^{c}$ \\
\hline Murray score & $3.5(3.0-3.5)$ & $3.5(3.0-3.5)$ & $3.5(3.3-3.8)$ & $0.42^{c}$ \\
\hline Retrieval case & $11(35.5)$ & $10(40.0)$ & $1(16.7)$ & $0.38^{\mathrm{B}}$ \\
\hline Infective causes & $28(90.3)$ & $24(96.0)$ & $4(66.7)$ & $0.09^{B}$ \\
\hline APACHE II score $†$ & $21.9 \pm 5.8$ & $21.0 \pm 4.8$ & $25.8 \pm 8.3$ & $0.07^{A}$ \\
\hline APACHE IV scoreł & $76.9 \pm 19.1$ & $73.4 \pm 15.7$ & $91.3 \pm 26.6$ & $0.17^{\mathrm{A}}$ \\
\hline Symptoms shown to ICU admission (days) & $7.0(3.0-8.0)$ & $7.0(3.0-7.5)$ & $8.0(5.3-10.5)$ & $0.22^{c}$ \\
\hline Duration of ventilator use prior to ECMO (days) & $0.7(0.2-1.3)$ & $0.7(0.3-1.3)$ & $0.3(0.1-3.4)$ & $0.32^{c}$ \\
\hline High limit of expected tidal volume $(\mathrm{mL}) \S$ & $390(318-420)$ & $404(324-420)$ & $324(296-420)$ & $0.32^{c}$ \\
\hline Tidal volume after ECMO (mL) & $288.0 \pm 76.8$ & $297.7 \pm 76.2$ & $247.6 \pm 71.5$ & $0.16^{\mathrm{A}}$ \\
\hline
\end{tabular}

Abbreviations: $\mathrm{APACHE}=$ Acute Physiology And Chronic Health Evaluation; BMI = body mass index; ECMO = extracorporeal membrane oxygenation; ICU = intensive care unit

* Data are presented as No. (\%), mean \pm standard deviation (SD), or median (interquartile range [IQR])

+ Of the 31 patients, the mean and SD of the expected risk of death as predicted from the APACHE $\|$ score was $0.42 \pm 0.19$

$\neq$ Of the 31 patients, the median and IQR of the expected risk of death as predicted from the APACHE IV score was 0.24 (0.I3-0.34)

$\S<6 \mathrm{~mL}$ per estimated body dry weight in $\mathrm{kg}$

\| Various tests were used: ${ }^{A}=$ independent $t$ test for comparison of means; ${ }^{B}=$ Fisher's exact test for categorical data; ${ }^{C}=$ Mann-Whitney $U$ test for comparison of medians 
(mean $\pm \mathrm{SD}, 42.2 \pm 14.1$ years; 21 males) received $\mathrm{v}-\mathrm{v}$ ECMO for the treatment of severe respiratory failure and ARDS. The median body mass index was 22.6 (IQR, 21.5-24.8) kg/m². The median Murray score was 3.5 (IQR, 3.0-3.5). A total of 11 cases were retrieved from other acute hospitals. The median time required for patients to arrive at the ICU was 7.0 (IQR, 3.0-8.0) days (Table 1). The mean duration of mechanical ventilation before starting ECMO treatment was $1.6 \pm 2.7$ days.

Male gender and younger age were associated with better survival rate, although they did not attain statistical significance. Survivors and non-survivors had similar Murray scores. Survivors had a higher pre-ECMO $\mathrm{PaO}_{2} / \mathrm{FiO}_{2}$ ratio, lower APACHE (Acute Physiology And Chronic Health Evaluation) II and APACHE IV scores, and shorter time for symptoms to ICU admission versus the non-survivors, but none of the differences was statistically significant (Table 1 ). Of the 31 patients who presented with respiratory failure, 28 (90.3\%) were diagnosed to have pneumonia, one had severe smoke inhalation injury, and two had status asthmaticus; 22 of the 28 pneumonia patients had identifiable laboratory causes (Table 2). Patients suffering from viral infection as primary cause of respiratory failure ( 1 dead/11 alive) had better ICU survival than those suffering from bacterial infection (2 dead/8 alive); however, the difference was not statistically significant ( $92 \%$ vs $80 \%, P=0.57$, Fisher's exact test; Table 2). Overall, nine (29.0\%) patients were diagnosed to have H1N1 infection, either by polymerase chain reaction or serology or both. Patients with H1N1 as the cause of respiratory failure had excellent survival outcome (100\%; Table 3).

The median (IQR) duration of ECMO therapy was 5.0 (2.8-8.6) days. The median length of ICU stay was 18.0 (11.6-25.8) days, and median length of hospital stay was 23.5 (15.3-40.9) days. A total of $25(80.6 \%)$ patients survived ICU discharge and 24 (77.4\%) patients survived hospital discharge and had 28-day survival (Table 4).

TABLE 2. Infective sources of patients with respiratory failure who required venovenous extracorporeal membrane oxygenation and their outcomes

\begin{tabular}{lcc}
\hline Primary pathogen & Total No. of patients & No. (\%) of ICU survivors \\
\hline Flu A* co-infected with Streptococcus pneumoniae & 2 & $1(50)$ \\
Swine H1N1 & 7 & $7(100)$ \\
Swine H1N1 co-infected with Streptococcus pneumoniae & 2 & $2(100)$ \\
Flu B co-infected with Streptococcus pneumoniae & 1 & $1(100)$ \\
Streptococcal pneumoniae & 6 & $4(67)$ \\
Mycoplasma species & 2 & $2(100)$ \\
Legionella pneumophila & 2 & $2(100)$ \\
\hline
\end{tabular}

Abbreviation: ICU = intensive care unit

* Excluded swine HINI

TABLE 3. Comparison of patients with HINI who required venovenous extracorporeal membrane oxygenation*

\begin{tabular}{|c|c|c|c|c|}
\hline & Present study & Hong Kong ${ }^{16}$ & $\begin{array}{c}\text { Australia and New } \\
\text { Zealand studies }^{14}\end{array}$ & Canadian study ${ }^{17}$ \\
\hline No. of cases & 9 & 7 & 61 & 6 \\
\hline Age (years) & $41 \pm 14$ & $42(39-50)$ & $36(27-45)$ & $22 \pm 16$ \\
\hline Male & $5(56)$ & $2(29)$ & $29(48)$ & $1(17)$ \\
\hline APACHE II score & $20.7 \pm 4.7$ & $17 \pm 3$ & - & $25 \pm 3$ \\
\hline ECMO duration (days) & $5.0(3.7-11.0)$ & $6(6-10)$ & $10(7-15)$ & $15(14-15)$ \\
\hline Ventilator duration (days) & $9.9(7.2-34.3)$ & $19(11-25)$ & $25(13-34)$ & $27(18-40)$ \\
\hline ICU LOS (days) & $23.2 \pm 18.3$ & $19(18-30)$ & $27(16-37)$ & $28(19-38)$ \\
\hline Hospital LOS (days) & $29.0 \pm 2.0$ & $31(25-55)$ & $39(23-47)$ & - \\
\hline ICU survival & $9(100)$ & $6(86)$ & - & - \\
\hline Hospital survival & $9(100)$ & $6(86)$ & $47(77)$ & $4(67)$ \\
\hline
\end{tabular}

Abbreviations: APACHE = Acute Physiology And Chronic Health Evaluation; ECMO = extracorporeal membrane oxygenation; ICU = intensive care unit; LOS = length of stay

* Data are shown as No. (\%) of cases, median (interquartile range), or mean \pm standard deviation 
TABLE 4. Results and outcomes of extracorporeal membrane oxygenation procedure

\begin{tabular}{|c|c|c|c|c|}
\hline & \multicolumn{3}{|c|}{ Median (interquartile range) } & \multirow[t]{2}{*}{ P value ${ }^{\star}$} \\
\hline & Total No. of patients $(n=31)$ & ICU survivors $(n=25)$ & ICU non-survivors $(n=6)$ & \\
\hline ECMO duration (days) & $5.0(2.8-8.6)$ & $5.0(3.1-8.4)$ & $4.3(2.3-22.9)$ & 0.90 \\
\hline Ventilator duration (days) & $18.2(7.8-27.9)$ & $18.2(7.9-30.5)$ & $18.6(4.7-31.3)$ & 0.96 \\
\hline ICU LOS (days) & $18.0(11.6-25.8)$ & $18.0(12.1-27.9)$ & $18.7(4.7-31.4)$ & 0.65 \\
\hline Hospital LOS (days) & 23.5 (15.3-40.9) & $28.1(17.3-41.6)$ & 18.7 (5.6-31.6) & 0.18 \\
\hline
\end{tabular}

Abbreviations: ECMO = extracorporeal membrane oxygenation; ICU = intensive care unit; LOS = length of stay

* Mann-Whitney $U$ test for comparison of medians

On logistic regression analysis, APACHE II score was the only significant factor that could predict hospital mortality.

Of the 31 patients, two (6.5\%) patients developed severe haemorrhage (haemothorax $[n=1]$ and cerebral bleeding $[n=1])$ and three $(9.7 \%)$ patients developed mechanical complications of the circuits (clotted membrane $[n=1]$, suspected oxygenator failure $[n=1]$, and vascular injury $[n=1])$.

\section{Discussion}

The first successful ECMO treatment case was reported in 1972. ${ }^{5}$ However, two randomised controlled trials ${ }^{6,7}$ that were published several years after this reported case failed to show any significant advantage with ECMO. The use of ECMO in adult patients remained limited until publication of the CESAR trial in 2009,3 which showed significant advantages with ECMO in terms of survival for patients with severe respiratory failure and ARDS after $\mathrm{H} 1 \mathrm{~N} 1$ pandemic.

Our patients, who were managed with $v-v$ ECMO for severe respiratory failure, had ICU mortality and hospital mortality of $19.4 \%$ and $22.6 \%$, respectively. Most of them $(n=29 ; 93.6 \%)$ had severe ARDS that failed conventional treatment. Our results (7 dead/24 alive) compared favourably with the ECLS (Extracorporeal Life Support) Registry Report ${ }^{8}$ in which the hospital mortality was reported to be $44 \%$ ( 2283 dead $/ 2905$ alive; $\mathrm{P}=0.018$ by Fisher's exact test). Mortality of ARDS, before 1990s, was higher than 50\%.9,10 Mechanical ventilator is the cornerstone of treatment for ARDS. Although it can support lung ventilation, inappropriate use can lead to lung damage including excessive transpulmonary pressure (barotrauma), excessive lung volume inside alveoli (volutrauma), and shearing stress during repetitive opening and closing of alveoli (atelectrauma). ${ }^{11}$ Moreover, the damage caused by mechanical ventilation is not limited to the lungs. Lung trauma can trigger systemic inflammatory response (biotrauma) that involves other distal organs leading to multiorgan damage. To date, the only strategy that can improve survival is lung protective strategy $(\leq 6 \mathrm{~mL} / \mathrm{kg}$ of predicted body weight; plateau pressure $\left.\leq 30 \mathrm{~cm} \mathrm{H}_{2} \mathrm{O}\right) .{ }^{12,13}$ With the use of lung protective strategy and ECMO treatment, recent publications reported a mortality of approximately $20 \%$ to $40 \% .^{3,14}$ Lung protective strategy was the most evidence-based approach in ARDS management. Extracorporeal membrane oxygenation use in ARDS patients can ensure the effective application of low tidal volume and plateau pressure strategy.

In our report, the mean tidal volume after ECMO therapy was $288.0 \pm 76.8 \mathrm{~mL}$, which was within the higher limit of the expected tidal volume (390 $\mathrm{mL}$ ) according to the lung protective strategy (Table 1). The ICU mortality and hospital mortality rates in our cases were $19.4 \%$ and $22.6 \%$, respectively. These figures are favourable when compared with patients who receive only lung protective strategy. ${ }^{13}$ In fact, ICU doctors often face challenges to comply with the lung protective strategy in real situation. The presence of stiff lung and hypercarbia in severe ARDS patients may make it difficult for ICU doctors to set low tidal volume and transpulmonary pressure. The use of ECMO, however, can overcome these challenges. Extracorporeal membrane oxygenation can allow both $\mathrm{CO}_{2}$ removal and oxygenation with an independent circuit that by-passes the sick lungs. This permits complete lung rest with the lung protective strategy.

H1N1 infection is widely reported to have better survival rate and shorter duration of ECMO support, mechanical ventilator days, and length of ICU stay. According to the ELSO (Extracorporeal Life Support Organization) registry (as dated to 13 April 2011), the $\mathrm{H} 1 \mathrm{~N} 1$ survival rate was $76.8 \%$ (66 dead/218 alive) in patients older than 20 years. ${ }^{15}$ In our study, all nine $\mathrm{H} 1 \mathrm{~N} 1$ swine flu patients survived (Table 2). H1N1 patients in Hong Kong had more favourable outcomes compared with those in Australia and Canada (Table 3). ${ }^{14,16,17}$ These outcomes included shorter ECMO duration, shorter ventilator days, and shorter ICU and hospital length of stay. Future study shall explore other factors that affect outcomes including duration of interhospital transportation, manpower availability, and use of pharmacological treatment. In our centre, 
all H1N1 patients received N-acetylcysteine (NAC) intravenous infusion together with oseltamivir from day 0 of ICU admission. The effect of NAC, an antioxidant ${ }^{18-21}$ as adjunct therapy in treating severe H1N1 respiratory infection, deserves further exploration in future.

In our study, vascular injury was the single complication that was related to the procedure. We encountered one oxygenator-related thrombosis and one suspected oxygenator failure. In one case, we postulated that the cause of thrombosis was hypercoagulopathy related to mycoplasma infection. Another case had contra-indication to heparin due to active bleeding. One patient was diagnosed with intracerebral bleeding after initiation of ECMO therapy. The bleeding was probably related to the patient's own brain pathology. The patient was diagnosed with haematological lymphoproliferative disease that probably infiltrated the brain and caused death, as suggested by the postmortem examination.

\section{Limitations}

Our report had several limitations. As ECMO therapy is relatively new in our centre, we have a limited number of cases. This study was a retrospective review of a single-centre experience. All patients who received ECMO therapy were carefully selected, and we did not have a control group to demonstrate the superiority of ECMO therapy. We only considered mortality as our main outcome and did not followup the long-term morbidity of the survivors. Future study with ECMO shall consider outcomes that cover physical, functional, and neuropsychological aspects.

\section{Conclusions}

Venovenous ECMO is an effective adjunctive therapy, useful as a life-saving procedure for carefully selected severe ARDS patients when the limits of standard therapy have been reached.

\section{References}

1. Bernard GR, Artigas A, Brigham KL, et al. The AmericanEuropean Consensus Conference on ARDS. Definitions, mechanisms, relevant outcomes, and clinical trial coordination. Am J Respir Crit Care Med 1994;149:818-24.

2. ARDS Definition Task Force, Ranieri VM, Rubenfeld GD, Thompson BT, et al. Acute respiratory distress syndrome: the Berlin definition. JAMA 2012;307:2526-33.

3. Peek GJ, Mugford M, Tiruvoipati R, et al. Efficacy and economic assessment of conventional ventilatory support versus extracorporeal membrane oxygenation for severe adult respiratory failure (CESAR): a multicentre randomised controlled trial. Lancet 2009;374:1351-63.

4. Ashbaugh DG, Bigelow DB, Petty TL, Levine BE. Acute respiratory distress in adults. Lancet 1967;2:319-23.

5. Hill JD, De Leval MR, Fallat RJ, et al. Acute respiratory insufficiency. Treatment with prolonged extracorporeal oxygenation. J Thorac Cardiovasc Surg 1972;64:551-62.

6. Morris AH, Wallace CJ, Menlove RL, et al. Randomized clinical trial of pressure-controlled inverse ratio ventilation and extracorporeal $\mathrm{CO}_{2}$ removal for adult respiratory distress syndrome. Am J Respir Crit Care Med 1994;149:295-305.

7. Zapol WM, Snider MT, Hill JD, et al. Extracorporeal membrane oxygenation in severe acute respiratory failure. A randomized prospective study. JAMA 1979;242:2193-6.

8. Extracorporeal Life Support Organization. ECLS Registry Report. International Summary. Jul 2013.

9. Villar J, Slutsky AS. Is the outcome from acute respiratory distress syndrome improving? Curr Opin Crit Care 1996;2:79-87.

10. Phua J, Badia JR, Adhikari NK, et al. Has mortality from acute respiratory distress syndrome decreased over time? A systematic review. Am J Respir Crit Care Med 2009;179:220-7.

11. Tremblay LN, Slutsky AS. Ventilator-induced lung injury: from the bench to the bedside. Intensive Care Med 2006;32:24-33.

12. Hickling KG, Walsh J, Henderson S, Jackson R. Low mortality rate in adult respiratory distress syndrome using low-volume pressure-limited ventilation with permissive hypercapnia: a prospective study. Crit Care Med 1994;22:1568-78.

13. Ventilation with lower tidal volumes as compared with traditional tidal volumes for acute lung injury and the acute respiratory distress syndrome. The Acute Respiratory Distress Syndrome Network. N Engl J Med 2000;342:13018.

14. Australia and New Zealand Extracorporeal Membrane Oxygenation (ANZ ECMO) Influenza Investigators, Davies A, Jones D, Bailey M, et al. Extracorporeal Membrane Oxygenation for 2009 Influenza A(H1N1) Acute Respiratory Distress Syndrome. JAMA 2009;302:1888-95.

15. Extracorporeal Life Support Organization. H1N1 ECMO Registry (as of April 13, 2011). ECLS Registry Report.

16. Chan KK, Lee KL, Lam PK, Law KI, Joynt GM, Yan WW. Hong Kong's experience on the use of extracorporeal membrane oxygenation for the treatment of influenza A (H1N1). Hong Kong Med J 2010;16:447-54.

17. Kumar A, Zarychanski R, Pinto $\mathrm{R}$, et al. Critically ill patients with 2009 influenza A(H1N1) infection in Canada. JAMA 2009;302:1872-9.

18. Nimmerjahn F, Dudziak D, Dirmeier U, et al. Active NFkappaB signalling is a prerequisite for influenza virus infection. J Gen Virol 2004;85:2347-56.

19. Geiler J, Michaelis M, Naczk P, et al. N-acetyl-L-cysteine (NAC) inhibits virus replication and expression of proinflammatory molecules in A549 cells infected with highly pathogenic H5N1 influenza A virus. Biochem Pharmacol 2010;79:413-20.

20. Prescott LF, Donovan JW, Jarvie DR, Proudfoot AT. The disposition and kinetics of intravenous $\mathrm{N}$-acetylcysteine in patients with paracetamol overdosage. Eur J Clin Pharmacol 1989;37:501-6.

21. Garozzo A, Tempera G, Ungheri D, Timpanaro R, Castro A. $\mathrm{N}$-acetylcysteine synergizes with oseltamivir in protecting mice from lethal influenza infection. Int J Immunopathol Pharmacol 2007;20:349-54. 